\title{
A RENOVAÇÃo SOCIAL DA CULTURA ATRAVÉS DA LINGUAGEM JURÍDICA
}

\section{Rafael Otávio Ragugnetti Zanlorenzi}

Mestrando em Direito pela UFPR.

e-mail: demiurgo13@brturbo.com.br

RESUMO: A constituição simbólica do real leva à conformação de conjuntos sistêmicos e assistêmicos de linguagem. Os jogos assistêmicos são qualidades simbólicas agregadas a todos os objetos da realidade, incluindo a realidade em si. A espontaneidade desses símbolos assistêmicos acaba resultando em processos de comunicação auto-gerados, sem um emissor consciente. Nesses casos, basta ao receptor desejar ler a mensagem contida no signo. Essa significação é o núcleo de formação de toda sorte de culturas. Elas se sobrepõem umas às outras por um processo revolucionário no qual um jogo de signos é substituído por outro. Essa transformação tem origem na incompatibilidade de signos com uma realidade que não aceita ser lida daquela maneira. A não aceitação gera a ansiedade por um novo quadro cultural, que é efetivamente construído na ação revolucionária. A linguagem de revolução pode, no entanto, ser transformada no instrumento de uma revolução passiva, se absorvida pelos símbolos instituídos. No que diz respeito ao Direito contemporâneo, o processo de absorção é muito comum, e oferece ora soluções de curto alcance, ora a fragmentação do movimento revolucionário em si. A transformação cultural, portanto, se vê constantemente ameaçada pelas vantagens argumentativas do status quo, que the oferecem vantagem na construção e manutenção de signos. A partir disso, será necessário que todas as concepções revolucionárias encontrem a unidade significante de que deveriam ser naturalmente portadoras para oferecer uma resistência apropriada e uma retomada da ação potencialmente criativa no seio da sociedade.

PALAVRAS-CHAVE: Comunicação. Cultura. Discurso. Emblema. Excluído. Instituição. Linguagem. Norma. Pós-colonialismo. Revolução. Significado. Significante. Signo. Sociedade. Símbolo. 


\section{INTRODUÇÃO}

Observar é uma maldição. Parece-se menos com uma possibilidade, ou uma habilidade, e mais com o peso que recai sobre os ombros da vítima observadora. Não pode ser dissociado da condição humana, como tantas outras coisas não o podem (se é que algo pode ser de fato dissociado de todo o resto), e ao mesmo tempo não floresce em benefícios senão para os mais atentos e obstinados, aqueles dispostos a refinar o processo de observar e a ordenar as conclusões.

Observar pesa nos ombros, portanto, pois para que seja de fato produtivo, deve antes ser um ato consciente. Talvez não demande a consciência de si mesmo, mas certamente demanda a consciência dos elementos que proporciona à razão. Sem essa determinação, o processo de observação se transforma em mero conhecimento do espaço, em simples dispositivo de apreensão de necessidades e demandas espaço-temporais.

Assim sendo, a observação cuidadosa demanda, antes de tudo, uma aptidão distintiva, uma procura pelas referências superficiais e pelos sinais que as camadas mais profundas permitem emergir.

Nossa época é especialmente apreciável nesse sentido. Ela oferece dimensões ricas, no que diz respeito à possibilidade de observações significantes e superficiais ${ }^{1}$. Mais que isso, ela é, na verdade, uma soma contínua de significações, e muitas vezes o símbolo apresenta uma implicação concreta ainda mais determinante que os próprios elementos significados.

\section{O CONCEITO AMPLO DE LINGUAGEM E SUAS RELAÇÕES}

Com isso em mente, passemos então à definição de linguagem que pretendemos adotar aqui. Não queremos permanecer restritos a elementos puramente formais da linguagem, como a construção de sentenças por meio de idiomas. Antes, queremos resgatar o eixo de composição da linguagem, já 
apresentado por Saussure dentro do universo dos idiomas, por assim dizer, e que compõe a linguagem de um conteúdo significado e de um signo que o expõe. Como fica esse fundamento dicotômico essencial, se aplicado à realidade em sua extensão completa?

Podemos compreender que a linguagem é, num sentido amplo, todo o espectro de elementos compostos de significação, ou seja, todo o jogo de conteúdos e de emblemas que representam algo em específico. Nesse sentido, toda a conjunção de signos apareceria como uma forma de linguagem, ainda que assistêmica.

Ponderemos a amplitude disso. Se considerarmos que todo elemento tem, em determinado momento, um significado - como estamos acostumados a dizer específico para cada indivíduo, então isso quer dizer que tudo tem um signo que representa seu conteúdo. Mais que isso, também significa que, para cada um, a cadeia de significados pode ser, em verdade, muito diferente, ainda que se baseie em um mesmo elemento.

Tomemos como exemplo uma caixa de música. O objeto pode ter diversas funções, e pode ser adquirido por alguém tendo em vista diferentes elementos. Pode-se tê-lo pelo aspecto geral da caixa, ou talvez pela música que toque. Certamente, pode-se afirmar que tais elementos são, antes de tudo, funcionais e estéticos. Mas cada um desses elementos tem uma dimensão a mais. Se a caixa é especialmente apreciada por seu aspecto, pode ser que ele evoque emoções e memórias especiais, graças a isso, em seu portador. Se a canção que toca lembrar ao seu dono uma pessoa, ou um momento especialmente memorável, ela assume um significado além daquele próprio a ela. Ou, se o objeto pertenceu a um ancestral, pode representar uma ligação especial da pessoa com suas raízes, ou com o ancestral que não mais está presente.

Há, por conseguinte, na estética e na funcionalidade, ou, enfim, em todas as características atinentes a um dado objeto, a possibilidade de muitos signos, e com isso a possibilidade de incontáveis comunicações. Devemos, portanto, numa

1 O termo "superficial" pretende acessar aquela dimensão exterior de todas as realidades e experiências, que significa de imediato. Isso agrega dois elementos principais: um, a possibilidade de se promover deslizamentos superficiais, como nos coloca Deleuze, ou seja, ligações puramente emblemáticas entre elementos significados. Por outro lado, também traz à tona uma concepção ampliada de linguagem, que não se restringe a aspectos aprisionados na palavra - ou seja, nos diversos idiomas - mas sim no que cada elemento significado apresenta ao sujeito em sua dimensão significante. 
concepção ampliada de linguagem, considerar certas variáveis que não estão presentes nas concepções ortodoxas.

Em primeiro lugar, o ato de comunicação passa a ser extremamente incerto. Ao contrário da consideração típica da linguagem como um código de signos sistematizados, a linguagem nesse sentido amplo não tem signos definidos, e as relações entre uns e outros acabam se tornando extremamente vagas.

Isso, contudo, não quer dizer que um signo não guarde relação com os outros, ou que um significado não guarde relação com outros. Na verdade, a soma de elementos significados, sendo significados dentro de um mesmo universo captável, necessariamente vincula-os uns aos outros, relativiza-os de maneira própria em cada soma de signos. Isso permite resgatar, de certa maneira, a noção de um deslizamento superficial signo-signo (Deleuze), em que o sentido se perpetua por outros signos, resgatando elementos de significados completamente distintos, por uma relação de aproximação de seus emblemas. ${ }^{2}$

Em segundo lugar, é possível perceber que a comunicação que se estabelece dentro de um processo tão amplo de linguagem é em si incontrolável. Mesmo que não haja a clara intenção de comunicação, algo estará sendo comunicado. Mesmo as intenções de não comunicar são, nesse sentido, atos de comunicação. Essa é a nossa primeira maneira de explicar a falha de comunicação na qual o emissor da mensagem comunica algo que alcança o receptor de maneira distorcida. Exemplos disso estão na má interpretação de palavras ou de gestos, ou na incompreensão de intenções. Aliás, esse tipo de relação defeituosa pode muito bem ser incorporada e encorajada em determinadas situações. Por exemplo, num ambiente de alta competitividade, é possível que a comunicação seja elaborada no

\footnotetext{
${ }^{2}$ A relação velho-novo parece ser o melhor exemplo, nesse sentido. Algo que parece pertencer a uma época anterior é considerado velho à medida que é confrontado, ou que convive, com elementos posteriores. $O$ modelo costumeiramente evocado para explicar as relações da pós-modernidade, em que construções antigas convivem com prédios de concepção futurista, é um exemplo perfeito, nesse sentido. $O$ arcaico só se faz arcaico pelo advento do novo. Ė claro, pode-se alegar que esses elementos fazem parte da natureza, do momento de concepção das construções comparadas. Mas, se ponderarmos por um segundo, não podemos considerar meramente por uma implicação histórica a presença de certos adjetivos dentro da essência do objeto. $\mathrm{Na}$ verdade, não podemos considerar nada na essência de um objeto, uma vez que toda reconstrução histórica, e mesmo as reconstruções subjetivas de compreensão de um dado objeto, são todas na verdade emblemas. Que é, por exemplo, o relato da vida de Napoleão, senão um emblema "dos pés à cabeça"? Não se tem sua história, tem-se a imagem histórica de Napoleão, e sua centralização como tema graças a feitos que, por valores contemporâneos, são considerados dignos de nota, dignos de comunicação. Assim é com os objetos significados: não estão tanto na sua natureza, depois que caem sob nossas vistas, depois que os consideramos dignos de atenção. Eles se fazem nossos pelo que simbolizam para nós, e nesse sentido são significados, e portanto pertencentes a relações de linguagem.
} 
sentido de criar falhas e, com essas falhas, gerar armadilhas para o receptor da mensagem. Infelizmente, muito comum.

Um terceiro aspecto, que também pode explicar esse defeito de linguagem, reside na existência de camadas diversas de significados dentro de um mesmo signo. Se, por exemplo, tomarmos uma construção especialmente elaborada, estruturada à moda jônica, teremos uma evocação dentro de sua estética. Contudo, para as pessoas que viram a história daquele prédio (por exemplo, um local de especial relevância em um episódio político) ele pode significar, com sua fachada elaborada, uma relação completamente diferente da primeira. $\mathrm{Na}$ verdade, os significados agregados podem muitas vezes se sobrepor aos significados originais. ${ }^{3}$

Um último e fundamental elemento deriva das renovadas relações sujeitoobjeto, ou melhor, da concepção de crescente influência da subjetividade na relação de composição do objeto na consciência. Se considerarmos que o objeto existe simbolicamente na consciência, e que é na verdade reconstruído dentro dela, podemos concluir que cada indivíduo terá uma visão específica de cada objeto. Isso significa que, potencialmente, cada indivíduo tem um signo só seu para um dado objeto. Mais que isso, como afirmamos acima, a existência de um objeto em um dado universo acaba permitindo uma interlocução (relativização) de seu significado por um deslizamento superficial que o conecta a realidades nem sempre condizentes. ${ }^{4}$ Dentro da subjetividade, por assim dizer, há uma metamorfose do signo. Assim como o colonizador tentou assimilar 0 indígena que the era completamente estranho, o indivíduo precisa compreender o novo. E a primeira maneira de acessar esse novo é através da concatenação do seu signo aos outros signos que já compõem a subjetividade.

3 Eis aqui um exemplo fundamental do teor emblemático da história. Ela é incorporada como linguagem, no sentido da cruz de Rosenstock, ou seja, é encadeada como signos, que organizam o conteúdo no tempo e no espaço. Mas seu conteúdo fica capturado por essa significação, à medida que seu substrato físico se degrada. Museus, por exemplo: que são eles, senão testemunhos que reorganizam, espaçotemporalmente, a história, numa linguagem acessível à contemporaneidade?

4 Um bom exemplo sobre isso? Colonização. O que as culturas colonizadas tinham a ver com as colonizadoras? Absolutamente nada. Uma relação de aproximação material jogou grupos diversos de signos uns contra os outros. Daí as reações brutais dos colonizadores, na desesperada tentativa de, num primeiro momento, achar um lugar para esses novos signos entre os seus, e num segundo momento, dar-lhes sistematicidade pelo derramamento absurdo de sangue que se promoveu. $E$, hoje, quando imaginamos contos de ninar, temos um saci ao lado de índios com seus arcos, e os brancos tomando conta de uma fazenda. E nos parece natural. Por quê? Porque os signos se transformaram, olharam-se e se relativizaram em função do choque, até que a convivência se tornasse natural dentro desse âmbito recomposto. 
Um exemplo: pela primeira vez, um homem é confrontado com uma sociedade marginal, que nunca vira antes. Como ele a assimila? Ele mede as diferenças dessa sociedade em relação à sua própria, ele tenta se definir dentro desse novo contexto. Em resumo, ele toma os grandes emblemas de um dado contexto, num primeiro momento, e reelabora essas significações dentro do que já conhece como significantes. Outro exemplo: o fato de se dar, aqui mesmo, exemplos. Aliás, quanto mais numerosos forem, melhor. Cada exemplo é uma forma de "re-designação", ou seja, de reformulação do signo daquele conteúdo, numa tentativa de comunicar esse significado com outros universos, outras experiências diferentes, outros signos.

\section{ENTRE O VELHO E O NOVO}

Essa concepção ampla de linguagem cria, na verdade, uma grande confusão. A linguagem deixa de ser instrumento de comunicação, e passa a ser simplesmente seu veículo, sua "ossada", por assim dizer. A comunicação passa a acontecer de uma maneira inusitada, descontrolada. Não depende do interesse do emissor, mas apenas da atenção do receptor. ${ }^{5}$

Contudo, se pensarmos toda a relação de linguagem em circunstâncias tão caóticas, não há de ser possível criar uma relação emissor-receptor. Há, contudo, um senso comum, um espaço de certa forma convencional, que toma certo número de signos, e concretiza, pela soma de elementos diferentes, um universo de reações plausíveis. Digamos que, diante da realidade da comunicação, e de sua corporificação em um número infinito de linguagens, há uma espécie de condensação de signos estritamente necessários em uma dada realidade, e esses signos se convertem em elementos de uma comunicação firme, com um índice mínimo de eventualidades, mas que, ao mesmo tempo, empobrece a realidade que comunica, tanto em seu aspecto objetivo, quanto subjetivo.

A questão que nos parece mais relevante, contudo, não diz respeito a uma qualificação da confiabilidade ou individualidade dos signos, mas sim à possibilidade

${ }^{5}$ O que nos faz pensar nos teóricos da conspiração, por exemplo. O espírito paranóico em geral pode ler sinais em tudo. Ele está, digamos, interessado em ler mensagens, que podem muito bem ser meras ilusões. São os símbolos pessoais, os signos do paranóico, que o desvinculam de uma realidade comunicacional coletiva. 
de comoção coletiva desses signos, que podem nesse sentido ser confiáveis ou não. Aqui, pretendemos resgatar as linhas gerais do pensamento de RosenstockHuessy, que aborda a idéia de uma linguagem social, com símbolos e discursos que, enquanto permitem a transmissão de conteúdos entre indivíduos, são ao mesmo tempo a declaração de aceitação ou rejeição de uma dada realidade.

Afirma ele que, em um dado momento, estabelece-se uma linguagem própria na sociedade, um conjunto de elementos relacionais, de maneiras de conceber a realidade em questão. O discurso utilizado para justificar as ações sociais é, então, o que estabelece o status quo.

Por outro lado, quando a insatisfação com determinados aspectos sociais cresce, é possível que grupos insatisfeitos levantem um clamor em relação à situação, criando assim um novo universo da linguagem. Esse novo universo estabelece nomes novos - desliza conteúdos para noções novas - e com essa nova nomenclatura promove uma readaptação desses signos a uma concepção revolucionária do real.

Assim, se tomarmos por exemplo a visão de Marx em relação à sociedade burguesa, entenderemos que ele redesenha as relações estabelecidas, sob a égide de seu materialismo histórico. Ele não está, na verdade, criando conceitos, não ao menos sem que antes tome novas perspectivas de uma realidade existente e a recontextualize, segundo o universo material dos excluídos, a partir de novos nomes para velhas relações.

Nesse sentido, o processo de revolução social pela linguagem está embasado antes no que se pode entender como uma "alquimia interior", na qual as velhas relações são reconstituídas segundo uma nova composição de elementos, em que uma nova linguagem é criada para confrontar elementos não conviventes na realidade antiga. Por exemplo, Marx acessa de maneira completamente diferente a relação de trabalho, a partir de elementos desconsiderados pelas construções ideais burguesas de então. Coloca objetos que convivem na mentalidade proletária perante uma linguagem arcaica que, herdeira de processos idealistas, ainda está presa em um universo que congrega elementos das altas classes, de uma forma geral.

Fica, portanto, estabelecido que a revolução como linguagem consiste na alteração do jogo de relativizações, e na transformação das relativizações 
individuais, que constituem a consciência necessária para a eclosão da revolução. Mas o mero movimento de linguagem é eficaz?

Devemos, então, considerar o processo de revolução em si, como concebido por Rosenstock-Huessy. A revolução é a persistência de uma nova linguagem sobre outra, velha. Na verdade, a nova linguagem interioriza a velha como o Outro, e a coloca como aquilo que deve ser "colonizado", por assim dizer. O novo pretende substituir o velho, nesse sentido, e condensar seus próprios signos como elementos do status quo.

Diante disso, temos duas possibilidades: uma, a de que o status quo não aceite essa nova linguagem, e portanto desista de integrá-la ${ }^{6}$, seja como for, não permitindo a "comunicação" entre o velho e o novo. Por outro lado, também é possível que a nova linguagem, diante da resistência, combata, convença e vença. Nesse caso, os próprios símbolos da linguagem revolucionária se transformam, gradativamente, "perdem o brado", como diz Rosenstock, e se transformam em fórmulas estáveis, voltadas para a edificação, e não tanto para o processo de transformação e superação.

É com base nessa relação velho-novo que podemos estudar as bases de significação social do Direito, e as relações de transformação havidas dentro de suas qualidades significantes.

\section{A TRANSFORMAÇÃO SOCIAL}

O sentido da transformação concebida guarda, por conseguinte, aspectos de confrontação entre o novo e o velho, e representam mesmo a sua constante convivência. A visão de Rosenstock-Huessy, contudo, está mais conjugada a uma linguagem de determinação emblemática de idéias, e a uma realidade comunicacional confiável, como a chamamos acima.

Devemos, ainda, considerar a possibilidade de uma linguagem deitada sobre todas as coisas, que não chega a ser universal, mas que pode ser intensificada numa visão coletiva através da formação de um senso comum, como vimos. A transformação de uma dada linguagem depositada sobre objetos convivas

${ }^{6}$ A integração de uma nova linguagem por uma velha linguagem seria similar ao processo que mais tarde seria denominado "revolução passiva", por Gramsci. 
tem dois aspectos essenciais. Em primeiro lugar, se são objetos de períodos diferentes, e portanto apresentam a confrontação do velho e do novo, elas são consideradas no sentido de revolução apresentado por Rosenstock-Huessy, e com isso ora serão mostras do status quo, ora estarão inseridas uma no contexto da outra como símbolos relativizados. Contudo, ainda que o antigo esteja relativizado dentro do universo do novo, ele não deixa de ser um testemunho de uma realidade passada, e portanto a possibilidade de uma revolução, não para o retorno ao antigo (cujas condições terão sido perdidas pela instituição de uma nova linguagem) mas para a possibilidade de um paradigma diferente do atual.

Por outro lado, o próprio estabelecimento de um senso comum representa um movimento paralelo ao de transferência do discurso rebelde para o discurso de situação. Não é, contudo, a mesma coisa, pois a individualidade de significados é um conceito separado do de conceito lingüístico de revolução. Ainda assim, há uma coincidência nesses movimentos, porque o status quo depende da agregação de diferentes posicionamentos sob a égide de uma mesma linguagem densificada.

Com base nesses dois elementos, é possível observar uma transformação mais relevante, de grande monta, que atinge não apenas a disposição dos objetos e as significações relativas, mas também a flexibilidade desses objetos em relação à realidade como um todo. Se considerarmos, por exemplo, a qualidade de uma associação qualquer, entenderemos que ela guardará para membros um significado, para não-membros, outro. Mais que isso, quando ainda jovem, essa associação representa toda uma cadeia de aspirações individuais, por sua indefinição no campo do real. Ela significa determinadas esperanças para cada indivíduo, e cada indivíduo faz dela, portanto, uma imagem diversa, cada um a tem em uma configuração significante diferente.

À medida que ela se condensa, que ela se concretiza e alcança espaços dentro das hostes da ação, ela ganha novas dimensões, agrega posições relativas e portanto, redefine seus significados. Sua representação passa, então, a ser mais uniforme, mas ao mesmo tempo perde algumas das características essenciais dos indivíduos que com ela tomaram contato. Isso pode, por exemplo, gerar o desapontamento em alguns, e ocasionar o afastamento de algumas pessoas. Pode, contudo, "casar" perfeitamente com a significação individual original de outros, que se aproximam. 
Essa idéia nos remete à noção do espelho de Boaventura de Sousa Santos. Para ele, a instituição é, antes de tudo, um espelho da sociedade, que reflete a percepção de um dado momento. Contudo, essa reflexão pode ganhar densidade, e pode acabar se tornando turva, opaca, uma estátua, para glorificar a si mesma, e para influenciar a sociedade que outrora refletira.

Essa metáfora condiz perfeitamente com a noção de linguagem que pretendemos aqui. Em um momento de implicações eminentemente subjetivas, o objeto significado guarda, em seu espaço significante, uma ponte, por assim dizer, com o indivíduo. Nesse momento - que pode ser ou a juventude do significante/significado, ou a sua novidade para o indivíduo - há uma expectativa construída que se baseia sobretudo nas relações de significação do sujeito em si. Por outro lado, a formação progressiva de um senso comum a respeito de um dado significado, acaba integrando de forma nem sempre positiva o círculo individual, e então o signo passa a assumir um caráter objetivo.

Com a sua objetivização, há um jogo de possibilidades abertas por parte do sujeito que percebe o conjunto significante/significado. Por um lado, pode aceitar o signo, que está de acordo com seu universo de signos, e abraçá-lo como válido. Por outro, pode rejeitá-lo, num desapontamento de suas expectativas. Em ambos os casos, o sujeito julga aquele signo, e desdobra a sua significação. Ele metamorfoseia ainda uma vez o signo, e o reinsere em seu sistema ou com uma agregação positiva a mais - por exemplo, a instituição $X$, em que depositei minha confiança, mereceu-a desde sempre, porque funciona - ou a partir de uma concepção negativa - pensei que o indivíduo $Y$ fosse honrado, mas estava enganado.

Outro ponto central reside no termo "expectativa". A idéia de geração de expectativas tem, em parte, relação com a significação futura de algo que ainda não ingressou propriamente no universo da ação, mas que ainda é profundamente uma concepção. Por outro lado, a significação futura tem uma tendência a ser, individualmente, a ressonância da consciência presente, e nesse sentido, a continuidade do significante presente.

A expectativa é, portanto, o organizador dos signos da linguagem no tempo, e mais que isso, aquilo que efetivamente cria a noção de tempo dentro da linguagem. Se ponderarmos cuidadosamente, passado e presente se confundem, 
em termos lingüísticos, pois tudo o que significa já passou. Mesmo o que se produz agora, se significa, é porque já foi produzido. A expectativa, que não deixa de ser presente enquanto ação, é o único modelo de planejamento temporal na linguagem, e ainda assim é extremamente efêmero, pois sua base está apenas na pretensa esperança de uma ressonância/rompimento da relação significado/signo. ${ }^{7}$

Diante disso, entende-se que espaço e tempo, dentro da linguagem, traduzem-se apenas por jogos de conexões subjetivas, de forma que essas dimensões, nesses termos específicos, não podem ser consideradas como determinantes dos limites da subjetividade. Quando se fala, por exemplo, que um homem "vive no século passado", por sua mentalidade retrógrada, quer-se dizer que ele ainda guarda signos atinentes a uma época perdida. Ainda assim, isso não pode ser compreendido de maneira absoluta, pois as condições seculares de emissão de signos que o sujeito preserva não existem mais, de forma que seu jogo de signos está certamente cortado por noções e esperanças que não pertencem "ao século passado". Em contrapartida, cada tempo, nos signos, é a soma de todos os outros, não mais entendidos como passado, presente, futuro, mas antes como memória, compreensão, ação e expectativa.

Estabelecemos, com isso, um novo fulcro essencial para o processo de significação, qual seja, a idéia de ação. Procuramos entender ação como todo e qualquer processo de manifestação consciente de um dado elemento (convicção ou expectativa) dentro da totalidade real (e nesse sentido a significação não deixa de ser ela própria uma ação). Lógico, instituições não têm consciência própria, mas são expectativas ou convicções de grupos, levadas a cabo através de movimentos de transformação, e nesse sentido são ações.

Esse rudimento que nós utilizamos pretende espantar um pouco a noção de uma sociedade estagnada. Na verdade, quando pretendemos aqui falar de uma transformação cultural da sociedade através de seus signos, não estamos diante de

${ }^{7}$ Claro, pode-se também argumentar que a relação de tempo se encontra na produção de signo após signo, e que há signos que significam o tempo, como a própria idéia de tempo, ou relógios, ou o termo "antes", ou o termo "depois". Mas que são essas conjugações simbólicas, senão remissões que pretendem organizar uma compreensão temporal? Se seguirmos o exemplo de Deleuze, e desligarmos esses aspectos de linguagem desses conteúdos iniciais, perceberemos que os símbolos são eles próprios separadores de espaço e tempo, e que, colocados juntos, na realidade significam com base em estruturas profundas, mas que poderiam ser reordenadas em inúmeras configurações diferentes. Por exemplo, há termos em outros idiomas que traduzem emoções que, em português, precisam de três ou quatro termos diferentes para que sejam definidas. A separação é extremamente relativa, e extremamente subjetiva. A linguagem, portanto, não está submetida a essas dimensões de espaço e tempo, mas é, de certa maneira, ela própria uma dimensão. 
um universo estagnado que precisa ser abalado (ainda que ele possa, segundo certos signos, ser considerado como estagnado). Mesmo o status quo constitui seu senso comum, seus signos confiáveis, a partir de uma sucessão de ações, de condensações de sua própria imagem.

$\mathrm{Na}$ verdade, a própria ruptura surge um pouco dessa noção de ação. A concepção de ação a partir de objetos que significam tem uma carga poderosa de elementos ideais, agregados a um signo diante da idéia inicial do objeto em questão. Quando através da ação esse objeto é constatado falho, pode-se observar a transformação das idéias agregadas ao signo, num primeiro momento, seguida da queda dos próprios signos que significam aquele objeto (e, por fim, à proposta de uma nova linguagem).

\section{O DIREITO E A TRANSFORMAÇÃO CULTURAL}

Especificamente no que diz respeito à esfera jurídica, tem-se como concepção tradicional a de que suas vias comunicacionais são defensoras arraigadas do status quo. Isso é per si um signo do Direito.

De fato, não se pode dizer que esse signo esteja equivocado. Ele é, na verdade, a constituição progressiva de um senso comum dentro de hostes críticas, que podem ser entendidas como elementos revolucionários e formadores de uma nova linguagem. Mas como se dá esse processo?

A constituição do Direito como linguagem está centrada em dois aspectos marcantes: um, o da óbvia dimensão da norma, atacada em geral de maneira central. Contudo, essa dimensão normativa, essencialmente significativa, é apenas uma expressão de todo um jogo de instituições internas ao universo jurídico, e que em parte são significadas na lei, e em parte através de suas ações.

Devemos aqui ter em mente que o processo de significação/ação/ conscientização está elaborado sobre todos esses elementos centrais do Direito de forma indistinta. Aliás, o Direito não se vê distinto, em certa medida, do próprio Estado, graças ao legado pós-revolucionário. Mas a questão central é que, ao significar, o Direito está entrecortado por dimensões infinitas de signos, e ao mesmo tempo seus signos se amontoam uns sobre os outros, envolvendo-se, engolindo-se e re-significando uns aos outros. 
Diante desse amálgama profundo, qualquer corte seria possível sobre as relações jurídicas, e novamente qualquer circunstância de contestação revolucionária seria possível. Contudo, contemporaneamente, o que se constituiu como uma sucessão de linguagens contestatórias reside em movimentos localizados em torno de causas determinadas, que questionam progressivamente a validade das ações das instituições e, com isso, rompem com seus significados e signos.

Soluções para a miséria, por exemplo, são altamente questionadas. As instituições estabelecidas, simbolizadas ora pela lei, ora pela soma de ações (frutíferas ou não) nos meios sociais, constituem signos e mais signos, intercalandose e integrando as subjetividades, num contexto de constante questionamento e reformulação.

A procura de certas esferas de dignidade, então, traduz-se na formação de uma linguagem revolucionária em seu âmago, questionadora do jogo de signos estabelecidos pelo Direito. Devemos, contudo, procurar compreender em que termos essa revolução se processa, sobretudo para as transformações culturais da América Latina, entrecortadas por tantos outros elementos que arrefecem a complexidade do tema.

A conjugação de fatores de criação da cultura no espaço latino-americano parte de pressupostos perigosos. Ela tem, sem dúvida, inúmeras brechas estabelecidas para a contestação institucional, e nesse sentido a significação é um processo em constante mudança. Contudo, a formação dos signos revolucionários está fundada em pressupostos ainda mais retroativos, e que de certa maneira, numa dimensão significante, acabam traindo suas próprias ações.

O fulcro essencial de muitas justificações de transformação cultural está fundado na realidade pós-colonial da América Latina. Isso significa que há uma percepção do embate inicial de signos desconhecidos, e as monstruosidades cometidas contra os derrotados nessa relação, que transcendem em muito o discurso (na melhor das hipóteses eufêmico) que podemos oferecer pela dinâmica dos signos. Contudo, nessa mesma dimensão, as relações que o processo revolucionário estabelece são exatamente as mesmas relações de destruição da linguagem antiga. O revolucionário, como sugerimos acima, não deixa de ser um colonizador, à exceção notável de sua hipossuficiência de ação. Ainda, é claro que as relações que se estabeleceram no colonialismo são muito diferentes das que 
existem hoje, o que por si só muda a natureza de signos inteiramente (basta imaginarmos a realidade de hoje, na expressão máxima de sua burocracia, em contraposição ao movimento de guerras e conquistas do passado). ${ }^{8}$

Ainda assim, o movimento de signos é muito semelhante, e não pode ser ignorado. Nesse sentido, como signo o que se propõe poderia ser bastante letal, se considerasse a eliminação plena da outra via. Contudo, o que se observa é que a ação institucional tem a tendência de propôr uma revolução passiva, no sentido de abranger os novos signos sob uma renovação retrógrada, e que o processo revolucionário adota entre suas vias a própria opção de uma revolução dos signos na sua fonte institucional tradicional.

O que se vê, então, é uma tentativa de ressignificar o próprio processo de significação! Por um lado, pretende-se ressignificar no sentido de intensificar, e por outro, no sentido de somar universos alternativos dentro do universo original. A ressignificação revolucionaria da cultura contemporânea é um processo de abrangência progressiva, enquanto o processo de significação do status quo é um de condicionamento formal das realidades.

Há significação nova? Se considerar a concepção funcional das instituições, sem dúvida que há. Contudo, se considerar o discurso geral da concepção do real, há uma certa dificuldade de transposição de barreiras. Nisso, há na verdade um esvaziamento do espaço de significação.

È importante observar, portanto, que o processo de significação em si, enquanto disputado pela profusão de alternativas que se levantam contra o status quo e pelo próprio status quo sofre uma transformação inconsciente. Ele deixa de ser um modelo de expressão revolucionária e se transforma no espaço de um debate de posições. Deixa, portanto, de explorar a totalidade de sua renovação de significados, e deixa essa tarefa precipuamente para a ação em si.

Dois círculos de transformação cultural, então, formam-se: de um lado, um que está voltado para a produção de ações não condizentes com as ações institucionais, e que nesse sentido significa depois de concretizar, e passa a

${ }^{8}$ É preciso ainda notar que, quando tratamos desse capítulo a respeito da constituição da linguagem pelo colonizador, não seguimos o posicionamento de Rosenstock. Ele teria qualificado uma tal relação como uma não comunicação, um período pré-comunicativo, seguido de um momento em que a linguagem nascente conduziu a um espaço de corte desse diálogo frágil e, em seguida, à guerra. Mas, como consideramos que mesmo o silêncio tem signos próprios, e é por conseguinte comunicação, não podemos aceitar esse elemento da teoria de Rosenstock, sob pena de incoerência. 
significar para justificar a ação, num processo criador semelhante a todos os outros processos geradores de cultura do passado. Por outro lado, a significação passa a ser compreendida como um processo de adequação de ações estabelecidas, que não podem sair de um universo de possibilidades pré-estabelecidas. A significação passa a ser, então, empregada em nome da condenação de ações renovadoras.

Em nosso primeiro modelo de transformação significante, temos na verdade a reprodução das condições que, em todos os períodos históricos, representaram um momento de edificação cultural. O modelo mais comumente considerado como tal é o da Modernidade, em que se promoveu o resgate de elementos culturais (e portanto significantes) de um Antigüidade perdida sob novas condições. Há, portanto, toda a característica de uma conexão superficial, simbólica, a partir da qual uma nova estrutura cultural e portanto um novo discurso são criados.

Esse processo ocorre em todo momento de rompimento paradigmático. Ele permite a opção por uma reconstrução cultural, e ao mesmo tempo abre espaços para a construção do novo. Essa é, na verdade, a principal dimensão de preocupação que temos quando tratamos de uma realidade pós-colonial. Afinal, o combate a aspectos herdados da colonização nada mais é que uma criação simbólica polarizada, opositora de toda a construção simbólica realizada através do movimento de colonização.

O que se deve ter em mente é que, em todo processo de constituição simbólica não se pode apenas estabelecer um jogo de relações significantes. $\mathrm{Na}$ verdade, deve-se igualmente procurar perceber como essas relações significantes são capazes de acessar o velho discurso, e com isso dirimir seus danos. Mais que isso, o processo deve ser considerado ao máximo em suas próprias brechas. $\mathrm{Na}$ verdade, toda construção significante é portadora de um defeito grave, qual seja, o de excluir necessariamente outros discursos (a própria expectativa totalizante pode ser, nesse sentido, a mais perigosa, pois informa a si mesma, através do signo da compreensão universal, a sua própria perfeição auto-referente, que não pode existir em conjuntos lingüísticos que nem sequer integraram as expectativas, mas que surgirão no futuro).

Assim sendo, a elaboração de questionamentos perante as ações institucionais falhas do Direito, elaborada em duas dimensões, ora corre o risco de se tornar uma simbologia domesticadora da ação, ora apresenta o perigo de 
condicionar uma nova realidade segundo símbolos que, com o tempo, vão se tornar estáticos e excludentes como o elemento que inicialmente fora enfrentado.

\section{CONCLUSÕES}

A transformação cultural, sobretudo no que diz respeito aos focos de reivindicação de direitos, é um processo de desconstituição de uma das instituições mais controversas e delicadas.

Quando tratamos da produção de um jogo de direitos do homem, estamos na verdade questionando toda a ação concretizadora das instituições oficiais do Direito, em torno de uma realização cultural da imagem ocidental do homem. Isso é, também, uma instituição em si.

O homem jurídico é, portanto, mais um elemento repleto de suas próprias simbologias. Ele é, na verdade, traduzido na lei, e essa tradução oferece ao homem concreto uma significação própria, densificada por símbolos e imagens de uma sociedade preparada, "nutrida", para inclui-lo. O homem jurídico é o elemento final, escolhido, por assim dizer, para integrar um universo perfeito. Assim traduz-se o indivíduo em sua simbolização jurídica.

Contudo, esse significado pode muito bem ser desmantelado, à medida que as inidividualidades ${ }^{9}$ se vêem excluídas desse campo de relações idílicas. Mais que isso, contudo, deve-se compreender que essa fenda enorme no processo de simbolização se estabelece no momento em que, para a formação de um debate consensual, não se encontra a capacidade dos excluídos em integrarem o círculo de discussão. Não há para eles equiparação, e esse desnível se desdobra em diversas dimensões.

Por um lado, falta-lhes o preparo necessário para a discussão simbólica, a consciência do que seja esse processo de simbolização e a possibilidade da reunião de argumentos contrários ao elenco do status quo. Não podemos nos iludir: num quadro social, raramente o melhor argumento vence. Possivelmente, a maior quantidade de argumentos tenha sua influência sobre os contendores, mas é mais provável que a argumentação que mais se aproxime do senso comum vença. $\mathrm{E}$ 
quem tem o senso comum, junto às hostes de relação de poder, senão o próprio status quo? Metade do embate já foi vencida pelo status quo, e nesse sentido as relações contemporâneas da contenda simbólico-social são bastante autênticas.

Por outro lado, a simbolização do excluído traz um prejuízo imenso para esse debate. Como Rosenstock coloca, o conservadorismo atua precisamente no defeito de não ouvir a outra parte. É um passo numa escala que pode gerar a guerra civil, mas que nem sempre o faz, pelas manobras do discurso. O caso é que, dentro desse sistema, em algum momento, o próprio contendor (recurso argumentativo velho, aliás) acaba sendo desqualificado. Isso acontece em muitas ocasiões e é facilmente visível na boca da comunidade média. É essa imposição de símbolos de guerra que se constitui no preconceito, e ele pode, aliás, existir tanto do lado hegemônico quando nas fileiras revolucionárias (sendo mais comum no aspecto hegemônico). Qualquer simbolização negativa é, nesse sentido, o preconceito, em sua definição pejorativa, claro. ${ }^{10}$

Esse contexto decadente do processo revolucionário, especialmente visível entre as sociedades portadoras de miséria crônica, constitui a base de significação da falta de funcionalidade na sociedade. Não é apenas a falta de resolução sobre situações ambientais, ou a falta de fundos para atender aos famintos, ou ainda a incapacidade de uma reforma agrária apropriada que fazem, por si mesmas, a crise do paradigma estabelecido. É, antes, a simbolização de um "homem higienizado", de arestas aparadas e aspecto formal impecável, que contradiz toda a realidade.

O signo, portanto, degradou-se, entrou em conflito. E quando a verdade social explodiu, novos elementos de significação entraram em cena, deteriorando os velhos signos e criando, antes de tudo, uma revolução de raízes unitárias, fundadas no desprezo pela condição humana.

A estética divisionista que se instaura pelos interesses de cada movimento contra-hegemônico não deixam de ser, nesse sentido, uma ressignificação das

${ }^{9}$ A concepção de individualidade é aqui empregada para designar a pessoa real, enquanto o termo sujeito serve para designar qualquer reconstrução simbolizada dentro de outras imagens ideais, como o sujeito de direitos.

10 Aqui usamos o conceito popular do preconceito, aquele que designa certo grau de desdém injustificado, de repulsão do Outro sem um processo de racionalização. Na verdade, a formação do "préconceito" é um processo mais amplo, e numa compreensão maior pode até ser bem-vindo, quando diz respeito à análise de condições estranhas ao sujeito. Aqui, contudo, não devemos desenvolver o tema nesse sentido, mantendo apenas o aspecto mais sombrio do termo para ilustrar nosso tema. 
relações revolucionárias segundo um aspecto puramente hegemônico, que aclimata todo o processo revolucionário a uma incoerência forjada e fomentada.

A simbologia perdida do homem deve, nesse sentido, ser retomada de maneira unitária, com a reconquista da ação por parte dos grupos revolucionários para a disseminação de uma nova simbolização do homem, que certamente terá seus defeitos, mas que igualmente haverá de suprir a demanda que o abandono da condição humana criou ao longo de séculos de burocratização e formalização das relações. 